\title{
SATELLITE ACCOUNT OF HOUSEHOLD PRODUCTION. METHODOLOGICAL REMARKS AND RESULTS FOR POLAND
}

\author{
Ilona Blaszczak-Przybycińska \\ SGH Warsaw School of Economics, Collegium of Economic Analysis, Warsaw, Poland \\ e-mail: iblasz@sgh.waw.pl
}

ORCID: 0000-0001-7712-7323

\section{Marta Marszalek}

SGH Warsaw School of Economics, Collegium of Economic Analysis, Warsaw, Poland e-mail: mmars1@sgh.waw.pl

ORCID: 0000-0002-6810-7977

(C) 2019 Ilona Błaszczak-Przybycińska, Marta Marszałek

This is an open access article distributed under the Creative Commons Attribution-NonCommercial-NoDerivs license (http://creativecommons.org/licenses/by-nc-nd/3.0/)

DOI: 10.15611 /eada.2019.1.05

JEL Classification: D13

\begin{abstract}
The household production is a big aggregate which has no reflection in the current European system of national accounts. The market value of that production accounts for less than 10$15 \%$ of the total household production. Generally, household production can be estimated using the input method. Unpaid household work is the main input. There were many proposals of the way of estimating household work, but most economists prefer the market cost method. The first full sequence of accounts, entitled the Household Production Satellite Account for Poland (HHSA) was developed for 2011. It was proven that the value of the household work constitutes approximately $80 \%$ of the total value of household production, while the total value of household production in relation to GDP amounted to approximately $36.5 \%$. Providing the regular calculation of the HHSA, which is a supporting tool for the core national accounts, will allow the recognition and better understanding of the transfers and interactions between the market and households. The value and size of the goods and services produced by households can be compared with similar products produced on the market by enterprises.
\end{abstract}

Keywords: household production, unpaid work, housework, satellite accounts, GDP.

\section{Introduction}

The value of household production is a significant aggregate which has not had its full reflection in the European System of National Accounts (ESA). A great amount of household production is not sold on the market hence it has not any market price, but this does not mean that household production is worthless. 
The fact that unpaid household work has a significant value was noticed many years ago. The first estimation was made by W.C. Mitchell in 1919 [Poissonnier, Roy 2013], who calculated the value of household work in the United States using a method based on a housekeeper's wage. This estimation was recalculated by $\mathrm{O}$. Havrylyshyn in 1976 and showed that the monetary value of household work constituted as much as $36 \%$ in relation to GNP.

There have been a lot of estimations of household work made by economists all over the world, but their results are not comparable as the methods and techniques of those valuations were not the same.

The main aim of the household production account is to identify the value of non-market household production which is not registered in the GDP. The calculation allows determining the real contribution of households in creating added value in the economy and allows conducting detailed analyses of the level and quality of life.

\section{Methodology and the source of data}

In 1999 Eurostat published Proposals for a Satellite Account of Household Production which were the effect of some years of investigations under the Framework Research Program. This was when the concept of satellite accounts emerged for all these fields which were very important, but had not been sufficiently reflected in the national accounts. The aim was to give such a proposal for the methodology of the satellite account of household production which would allow all the European countries to create comparable and harmonized accounts of household production. There was a widespread discussion about the methodology of household production estimation and finally the input method was proposed.

The monetary value of the main input, i.e. household work, can be calculated using the market cost method or the alternative cost method. According to the former, the time used for performing different household activities can be valued according to the costs of market services similar to the home activities. For instance, the market cost of laundry services or alternatively the wage of laundry workers can be used for the estimation of the time spent on unpaid laundry at home. On the other hand, the value of time spent on household work can also be calculated based on the average wage in the country [Eurostat 2003; BłaszczakPrzybycińska 2008].

Such household production estimations can be made and they can be comparable between European countries as European harmonized time use surveys (TUS) have been conducted for several years in the framework of public national statistics. 
The estimation of household work in Poland according to the Eurostat Proposals was made twice using the data from harmonized time use surveys made in 2003/2004 and 2013 [Błaszczak-Przybycińska 2005; Błaszczak-Przybycińska, Marszałek 2015]. The sample size was appropriately 20,000 and 45,000 respondents, respectively.

In these estimations the unpaid household work was divided into four groups: household upkeep, food preparation, making and care for textiles (clothes), child care and adult care. Additionally, all household activities made on behalf of other households (e.g. shopping for the neighbors or childcare performed by a grandmother who lives separately) were also estimated.

The list of activities within the first group was the following: household construction and renovation; repair of the dwelling; making, repairing and maintaining household equipment; other construction and repairs; supply of heating and water; cleaning the dwelling and utility rooms; cleaning yard, snow removal; other household upkeep; travel related to household care; vehicle maintenance; various household arrangements. Food preparation related activities were: food preparation, baking; dish-washing; other housework; shopping; gardening; tending domestic animals; travel related to shopping and services. Handicraft and producing textiles; commercial and administrative services; other shopping and services; other making and care for textiles; laundry; ironing and drying were placed within the third group of household activities i.e. making and caring for textiles. The list of activities related to childcare and adult care consist in: physical care and supervision; teaching the children; reading, playing and talking with children; accompanying children; other childcare; travel related to childcare; helping an adult; travel related to an adult family member; caring for pets; walking the dog and other pets; other gardening and pet care; household management and child time coordination. There were as many as 36 household activities performed on behalf of one's own household and additionally 10 household activities performed for the other households. The value of household work was calculated separately for women and men.

The results of household work estimation were broken down by gender, activity on the labour market, family status by number of children, marital status of respondents including the age of household members, place of living, number of household members and the level of education.

The first stage of the estimation entailed calculating the average time per day for each of the 46 specified activities. The average time of the $a$-th activity duration in the $j$-th activity group for all days of the week was calculated separately for all the selected groups of respondents [Błaszczak-Przybycińska 2007]:

$$
{ }_{F} \bar{t}_{l a j}^{z}=\frac{\sum_{i=1}^{n_{1}}{ }_{F} t^{z}{ }_{i l a j}}{n_{F}}
$$




$$
{ }_{M} \bar{t}_{l a j}^{z}=\frac{\sum_{i=1}^{n_{2}}{ }_{M} t^{z}{ }_{i l a j}}{n_{M}}
$$

where: ${ }_{F} t_{i l a j}$ - duration of the $a$-th activity in the $j$-th group for the $i$-th woman from the $l$-th class in the $z$-th day of the week, $n_{F}$ - the number of women in a subsample, ${ }_{M} t^{z}{ }_{i l a j}$ - duration of the $a$-th activity in the $j$-th group for the $i$-th man from the $l$-th class in the $z$-th day of the week, $n_{M}$-the number of men in a subsample, $z$-the day of the week; $z=1,2,3$, where: 1 - MondayFriday, 2 - Saturday, 3 - Sunday, $j$ - group of domestic activities, $j=1,2$, $3,4,5$.

All activities performed by household members to satisfy their own needs are characterized by weekly seasonality. Hence the time spent in a week on domestic work was calculated as the weighted average using the days of the week. The weight of 5/7 was used for weekdays from Monday to Friday and 1/7 for Saturday and Sunday. The weighted average time was calculated separately for men and women:

$$
\begin{aligned}
{ }_{F} \bar{t}_{l a j} & =\left[\frac{5}{7}{ }_{F} \bar{t}_{l a j}^{1}+\frac{1}{7}\left({ }_{F} \bar{t}_{l a j}^{2}+{ }_{F} \bar{t}_{\text {laj }}^{3}\right)\right] \times 7 \\
{ }_{M} \bar{t}_{l a j} & =\left[\frac{5}{7}{ }_{M} \bar{t}_{l a j}^{1}+\frac{1}{7}\left({ }_{M} \bar{t}_{\text {laj }}^{2}{ }_{M} \bar{t}_{\text {laj }}^{3}\right)\right] \times 7
\end{aligned}
$$

where: ${ }_{F} \bar{t}_{l a j},{ }_{M} \bar{t}_{l a j}$ - the average week time duration of the a-th activity in the $j$-th group for the $i$-th woman and man from the $l$-th class, ${ }_{F} \bar{t}_{\text {laj }}^{1},{ }_{M} \bar{t}_{l a j}^{1}-$ the average duration of the $a$-th activity in the $j$-th group for women and men from the $l$-th class (weekdays from Monday to Friday), ${ }_{F} \bar{t}_{\text {laj }}^{2},{ }_{M} \bar{t}_{\text {laj }}^{2}-$ the average duration of the $a$-th activity in the $j$-th group for men and women from the l-th class (on Saturdays), ${ }_{F} \bar{t}_{\text {laj }}^{3},{ }_{M} \bar{t}_{\text {laj }}^{3}$ - the average duration of the $a$-th activity in the $j$-th group for men and women from the l-th class (on Sundays).

The average weekly value of housework per person from the $l$-th class selected according to socio-demographic characteristics was calculated separately for men and women:

$$
\begin{aligned}
{ }_{F} h_{l} & =\sum_{j=1}^{4} \sum_{a=1}^{n_{a}}{ }_{F} \bar{t}_{l a j} S_{a j} \\
{ }_{M} h_{l} & =\sum_{j=1}^{4} \sum_{a=1}^{n_{a}}{ }_{M} \bar{t}_{l a j} s_{a j}
\end{aligned}
$$


where: ${ }_{F} h_{l}$ - weekly housework value for a woman from the $l$-th class, ${ }_{M} h_{l}-$ weekly housework value for a man from the $l$-th class, ${ }_{F} \bar{t}_{l a j}$ - average duration per week of the $a$-th activity in the $j$-th group for women from the $l$-th class, ${ }_{M} \bar{t}_{\text {laj }}$ - average duration per week of the $a$-th activity in the $j$-th group for men from the $l$-th class, $\mathbf{s}_{a j}$ - hourly wage calculated for the $a$-th activity in the $j$-th group.

The average monthly value of domestic work for men and women in May 2013 was calculated by multiplying the weekly value by the number of weeks in a calendar year (52) and dividing the result by 12 .

$$
\begin{gathered}
{ }_{F} H_{l}=\frac{52}{12} \sum_{j=1}^{4} \sum_{a=1}^{n_{a}}{ }_{F} \bar{t}_{l a j} s_{a j} \\
{ }_{M} H_{l i}=\frac{52}{12} \sum_{j=1}^{4} \sum_{a=1}^{n_{a}}{ }_{M} \bar{t}_{l a j} s_{a j}
\end{gathered}
$$

where: ${ }_{F} H_{l}-$ monthly housework value for a woman from the l-th class, ${ }_{M} H_{l}-$ monthly housework value for a man from the $l$-th class.

The average hourly wages were supplied by the Survey of Wages According to Professions which has been conducted in Polish public statistics since 1996. The sample size is 700,000 workers and the survey is made in October, every two years (hence the hourly wages were recalculated using the monthly wage dynamics rates). In order to combine the household activity with the corresponding market service, the hourly wages were taken for the following professions: building frame and related trades workers; building finishers and related trades workers; painters; building structure cleaners and related trades workers, machine operators and assemblers; machinery mechanics and fitters; physical and engineering science technicians; transport and warehouse labourers; domestic, office, hotel helpers and cleaners; car and window cleaners, laundry workers and related cleaners; building caretakers; car, van and motorcycle drivers; cooks; waiters and barman; meal preparing labourers; food processing and related trades workers; market gardeners and animal producers; textile, garment and related trades workers; office clerks; nurses; midwives; other teaching professionals; primary and pre-primary education teaching professionals; personal care and related workers. All the above mentioned professions are specified in the Survey of Wages According to Professions 2012 [GUS 2014] and an average hourly wage is ascribed for all of them. 


\section{Empirical results of household work estimation}

The average monthly gross value of household work in Poland in May 2013 was 1672 PLN per capita (Table 1). This accounted for as much as $46.3 \%$ of the average monthly gross wage in Poland in May 2013. The monthly value of housework calculated for a woman (2113 PLN) was 73.5\% higher than the value calculated for a man (1218 PLN). The total value of household work in Poland in relation to GNP calculated using the share of women and men in the country was about $40 \%$ in 2013.

The average value of work done by an unemployed woman was higher than the value calculated for an employed woman (by 15\% in 2004 and 16\% in 2013). In the case of men the difference was much higher: the value of work done by an unemployed man was higher than the value calculated for an employed man (by $28 \%$ in 2004 and $21 \%$ in 2013 ).

The monthly value of unpaid domestic work made for other households was 99 PLN per capita in 2013 and was only $5.6 \%$ of the total housework value.

Table 1. The average monthly value of household work in May 2004, May 2013 (in PLN) and its dynamics (in \%)

\begin{tabular}{|c|c|c|c|c|c|c|c|c|}
\hline \multirow{3}{*}{ No } & \multirow{3}{*}{ Specification } & \multicolumn{7}{|c|}{$\begin{array}{l}\text { Average monthly value of household work per capita } \\
\text { (in PLN) and its dynamics }\end{array}$} \\
\hline & & \multirow[b]{2}{*}{ total } & \multicolumn{3}{|c|}{ females } & \multicolumn{3}{|c|}{ males } \\
\hline & & & total & $\begin{array}{l}\text { emplo- } \\
\text { yed }\end{array}$ & $\begin{array}{l}\text { unem- } \\
\text { ployed }\end{array}$ & total & $\begin{array}{c}\text { emplo- } \\
\text { yed }\end{array}$ & $\begin{array}{l}\text { unem- } \\
\text { ployed }\end{array}$ \\
\hline \multirow[t]{3}{*}{1} & Household upkeep & 204.58 & 191 & 160.07 & 203.45 & 233.22 & 192.66 & 279.72 \\
\hline & 2013 & 297 & 282 & 227.54 & 313.69 & 303.55 & 259.39 & 413.62 \\
\hline & dynamics 2013/2004 & $45.3 \%$ & 47. & $42.2 \%$ & 54 & $30.2 \%$ & $4.6 \%$ & $47.9 \%$ \\
\hline \multirow[t]{3}{*}{2} & paration & 479.05 & 656.33 & 570.05 & 705.08 & 300.30 & 226.16 & 393.34 \\
\hline & 2013 & 75 & 979.81 & 794.82 & 1111.59 & 504.53 & 382.81 & 715.35 \\
\hline & dynamics 2013/2004 & $57.2 \%$ & $49.3 \%$ & $39.4 \%$ & $57.7 \%$ & $68.0 \%$ & $69.3 \%$ & $81.9 \%$ \\
\hline \multirow[t]{4}{*}{3} & caring & & & & & & & \\
\hline & 2004 & 3.07 & 89.96 & 84.24 & 96.46 & 17.81 & 14.47 & 24.01 \\
\hline & 2013 & 63.79 & 102 & 81.12 & 118.08 & 22.75 & 15.73 & 33.93 \\
\hline & dynamics 2013/2004 & $9.9 \%$ & $13.6 \%$ & $-3.7 \%$ & $22.4 \%$ & $27.7 \%$ & $8.7 \%$ & $41.3 \%$ \\
\hline \multirow[t]{6}{*}{4} & Childcare and adult care & 258 & 328.25 & 343.94 & 325.43 & 176.63 & 206.57 & 120.73 \\
\hline & 2013 & 557.44 & 748.67 & 821.47 & 694.07 & 387 & 474.85 & 206.96 \\
\hline & dynamics 2013/2004 & $115.8 \%$ & $128.1 \%$ & $138.8 \%$ & $113.3 \%$ & $119.2 \%$ & $129.9 \%$ & $71.4 \%$ \\
\hline & of which: childcare 2004 & 216.28 & 289.94 & 313.91 & 283.31 & 131.73 & 174.68 & 67.70 \\
\hline & 2013 & & & 768.47 & & 321 & 42 & 119.6 \\
\hline & dynamics 2013/2004 & $128.5 \%$ & $133.7 \%$ & $144.8 \%$ & $112.3 \%$ & $143.9 \%$ & $144.3 \%$ & $76.1 \%$ \\
\hline \multirow[t]{4}{*}{5} & Unpaid work for other & & & & & & & \\
\hline & households & 70.03 & & 39.30 & 91.48 & 67.43 & 48.53 & 101.27 \\
\hline & 2013 & & 107 & 46.24 & 163.06 & 74.19 & 36.40 & 130.61 \\
\hline & $13 / 2004$ & $40.7 \%$ & $69.7 \%$ & $17.7 \%$ & $78.2 \%$ & $10.0 \%$ & $-0.25 \%$ & $29.0 \%$ \\
\hline \multirow[t]{3}{*}{6} & Groups 1-4 together & $1,000.00$ & $1,265.72$ & $1,158.30$ & $1,330.42$ & 727.96 & 639.86 & 817.79 \\
\hline & 2013 & $1,671.63$ & 2113.24 & $1,924.95$ & 2237.43 & 1218.01 & 1132.78 & 1369.85 \\
\hline & $3 / 2004$ & $67.2 \%$ & $67.0 \%$ & $66.2 \%$ & $68.2 \%$ & $67.3 \%$ & $77.0 \%$ & $67.5 \%$ \\
\hline \multirow[t]{3}{*}{7} & Groups 1-4 together & 1070.03 & 1329.25 & 1197.60 & 1421.90 & 79 & 688.39 & 919.06 \\
\hline & 2013 & $1,770.17$ & $2,221.05$ & $1,971.19$ & $2,400.49$ & $1,292.20$ & $1,169.18$ & $1,500.46$ \\
\hline & dynamics 2013/2004 & $65.4 \%$ & $67.1 \%$ & $64.6 \%$ & $68.8 \%$ & $62.5 \%$ & $69.8 \%$ & $63.3 \%$ \\
\hline
\end{tabular}

Source: [Błaszczak-Przybycińska, Marszałek 2015, p. 164]. 
The structure of the total value of household work by type of activity is presented in Table 2. The highest share was observed for food preparation which accounted for $46 \%$ of the total value for women and $41 \%$ for men in 2013 (in 2004 it was $51 \%$ for women and $41 \%$ for men). The high value of domestic work was also noted in child and adult care. It constituted $35 \%$ of the total value of work done by women and $32 \%$ by men (in 2004 it was $26 \%$ for women and $24 \%$ for men). The lowest value of work was observed for making and caring for textiles. One of the reasons is that the market services are well developed in this field. The value of making and caring for textiles in households constituted only $5 \%$ of the total value of work done by women and $2 \%$ by men (in 2004 it was $7 \%$ for women and $2 \%$ for men). The share of household upkeep in 2013 was $25 \%$ of the total value for women and 15\% for men. In 2004 the share of household upkeep for men was as much as $32 \%$ of the total value of household work done by men. This was the only group of domestic activities when the absolute value of work was higher for men than for women.

Table 2. Structure of household work according to type (in \%)

\begin{tabular}{|r|l|r|r|r|r|r|r|}
\hline \multirow{2}{*}{ No } & \multirow{2}{*}{ Type of housework } & \multicolumn{3}{|c|}{ Structure (in \%) 2013} & \multicolumn{3}{c|}{ Structure (in \%) 2004} \\
\cline { 3 - 8 } & & total & females & males & total & females & males \\
\hline 1 & Household upkeep & 17.8 & 15.4 & 24.9 & 20.5 & 15.1 & 32.0 \\
\hline 2 & Food preparation & 45.0 & 46.4 & 41.4 & 47.9 & 51.9 & 41.3 \\
\hline 3 & Making and care for textiles & 3.8 & 4.8 & 1.9 & 5.8 & 7.1 & 2.4 \\
\hline 4 & Child care and adult care & 33.4 & 35.4 & 31.8 & 25.8 & 25.9 & 24.3 \\
\hline 5 & Total & $\mathbf{1 0 0 . 0}$ & $\mathbf{1 0 0 . 0}$ & $\mathbf{1 0 0 . 0}$ & $\mathbf{1 0 0 . 0}$ & $\mathbf{1 0 0 . 0}$ & $\mathbf{1 0 0 . 0}$ \\
\hline
\end{tabular}

Source: [Błaszczak-Przybycińska, Marszałek 2015, p. 167].

Many economists point out that the estimation of household value based on different wages combined with the professions corresponding to household activities, brings detailed and accurate results but is very laborious. Hence some of them recommend using the same rate based on, for example, the average wage in the country which make easier the calculation of household production.

One and the same rate for housework estimation can be calculated as the total value of household work (estimated using different wage rates according to professions) divided by the total number of hours aimed at all household activities. For Poland such a recalculation (based on detailed wage rates for different professions in October 2012 and in October 2002) gave the rates at the level of $69.8 \%$ of the average wage in the country (October 2012) and $68.8 \%$ (October 2002). Hence the rate of about $70 \%$ of the average wage can be accepted but the dynamics of the average wage in the country is not the same as the dynamics of the professions parallel to domestic work. 


\section{Household production and the national accounts}

Household production (goods and services produced for the household's own use) is the most significant part of the total household production excluded from the core national accounts. Household production (home production) consists of four main components: paid (market household production) and unpaid work (housework), intermediate consumption and capital consumption (depreciation). The major part of the home production is unpaid work. In EU countries, market household production which generates household market income is estimated at approximately $10-15 \%$ of the total home production. The gap of the other productive components of the household production is still unobserved and unregistered in the official statistics, so it is invisible in the whole economy. Although home production is not covered by global production, gross national income or GDP, it generates the major part of total household production, and without its the economy does not exist. Non-market home production which is made for own use to meet individual or family needs, it has no market price but it has a value.

For decades, international economists and national statistics experts have been discussing the possibility of measuring household production, especially nonmarket household production, showing the results in the same accounting method as in the case of any other production. Measuring the value of this economic category is a crucial issue contained in the Eurostat recommendations and in the Stiglitz-Sen-Fitoussi commission report [Stiglitz, Sen, Fitoussi 2009]. The latter emphasizes the influence of household production on measuring social and economic well-being.

Studies on the valuation of unpaid work and non-market household production have a long worldwide tradition, but there is no consensus reached in the field of common methodology. Methods using inputs are applied more often [Varjonen et al. 1999; Szép 2003; Schäfer 2004; Varjonen, Aalto 2006, 2010; Ruger, Varjonen 2008, Hamunen,Varjonen, Soinne 2012; Poissonnier, Roy 2013] than methods based on outputs [Holloway, Short, Tamplin 2002; Fender 2012] which are compatible to productivity measurement and GDP formation. In spite of that, a crucial decision on estimation was reached suggesting that the valuation of unpaid work should be calculated using one of three different approaches: replacement cost, average cost and opportunity cost [OECD 2010; Kuwahara 2010]. This practically gives us the basic information on the labour of housework and household production valuation.

Many researchers and economists suggest that direct methods of measurement of household production are the most desirable for valuing the output of households, and that direct calculation is difficult but feasible [Becker 1990a, 1990b; Goldschmidt-Clermont 1993; Ironmonger 1996; 1997; Varjonen, Aalto 
2006]. Moreover, direct measurement is more intensive and more laborious than econometric modelling, but it is still the most appropriate method that uses all important data from many different sources from the national statistics (household budget survey, time use survey, national accounts, national population census etc.).

Calculation of the value of household production could be estimated through econometric modelling, providing the household production function. Knowledge of that function allows us to understand the economic roles performed by men and women in households. The studies [Gronau, Hamermesh 2008; Gronau 1980; Graham, Green 1984; Fitzgerald, Swenson, Wicks 1996; Rapoport, Sofer, Solaz 2011] have made a significant contribution to this topic. All of these compilations employed indirect methods of estimating the household production function.

\section{Household production satellite account}

The basis for analysis and to realize the Household Production Satellite Account (also known as Household Satellite Account - HHSA) is Becker's theory of time use allocation and "productive" consumption [Becker 1990a; 1990b]. Households have a dual role in the economy. On the one hand, they have a consumer's role in that they purchase goods produced on the market. On the other hand, they provide a valid share of the goods and services produced in the whole economy, i.e. childcare and adult care services, preparing meals, making and caring for textiles, cleaning, and gardening. Households are also engaged in significant activities that create added value and generate a social welfare. A significant part of that production is the market not covered yet, so the goods and services which are produced do not have market prices but are valuable.

The inevitability of the measurement of unpaid work and household production was perceived in the 1930s. M. Reid [1934] noted that the productivity of the household had been overlooked, even though households focused more on "workers" than any other industry. Accordingly, households could be compared to enterprises because they provide goods and services which if they do not produce, they would have to buy on the market. Reid put into practice "the third party criterion", also known as the "productivity criterion", which applied a borderline to distinguish between productive and non-productive activities. The valuation of labour and household production can be made only for those activities that can be carried out and delegated to someone else, or might be replaced by other market goods or paid services without a reduction of a utility for a given household.

In economic practice the household production satellite account should be an additional and supporting statistical tool to the official statistics with a comprehensive overview of the current social-economic situation of households.

The starting point to organize the HHSA is to measure the value of home production and calculate its main components: housework, intermediate consumption and capital consumption. 
Total household production was estimated according to formula (9) [Marszałek 2015]:

$$
H P=S N A H P+\text { non SNA HP }
$$

where: $H P$ - total household production (market and non-market), SNA HP market household production (included in the national accounts and GDP), non SNA HP - non SNA (excluded from the System of National Accounts) household production (home production excluded from the national accounts and GDP).

Household production produced for own needs by household members or to other family and other households was evaluated according to formula (10):

$$
\text { non } S N A H P=H W+I C+F C+D
$$

where: non SNA HP - non SNA (excluded from the System of National Accounts) household production (home production excluded from the national accounts and GDP), $H W$ - housework (unpaid work produced for own use in the household or for other households), $I C$ - intermediate consumption, $F C$ - final consumption, $D$ - depreciation.

Housework is the major and most important part of the total home production, because its share of the household production is the largest. In order to describe the complex roles of productive activities, to recognize producers and receivers of housework, home production was calculated by different principal functions, i.e. providing housing, preparing meals and snacks, making and care of textiles (i.e. clothes and shoes), child and adult care, and volunteer work. Also shopping, travel related to unpaid work, and household management are shown separately in a household satellite account.

Home production and unpaid work which are not included in the GDP and in the national accounts are valued by using the input method. A more appropriate approach is the output method because it provides comparability with other productive activities obtained in the economy. The main disadvantage of the output method is that it does not encompass all the products and services realized in the households. Some services done for themselves are difficult to recognize as the result of housework, i.e. childcare and volunteer work. The input method is wellknown and generally most often used in calculations.

\section{Valuing consumption}

The household satellite account provides information on three types of consumption: final consumption, intermediate consumption, and depreciation.

Final consumption means the direct usage of product: eating food (e.g. icecream, snacks, yogurts, fruits), and wearing clothes. The second type is 
intermediate consumption, consisting in the goods or services used during the production process to create new products, for example meat and vegetables to prepare lunch. Finally, there is the consumption of capital, which consists of two items: consumption of fixed capital (depreciation of equipment, machinery and household appliances) and interest on the acquisition of capital. In the Household Satellite Account for Poland, only consumption of fixed capital (depreciation) was calculated.

Table 3. Selected items of households capital goods, estimation of average time of using goods (in years), proportion of consumption (in \%)

\begin{tabular}{|c|c|c|c|}
\hline $\begin{array}{c}\text { COICOP* } \\
\text { Classification }\end{array}$ & $\begin{array}{c}\text { Household capital } \\
\text { (durable and semi-durable goods) }\end{array}$ & $\begin{array}{l}\text { Average } \\
\text { time of use } \\
\text { (in years) }\end{array}$ & $\begin{array}{c}\text { Percentage } \\
\text { of consumption in } \\
\text { average time of use }\end{array}$ \\
\hline 051111 & Furniture (with mattresses) & $10-15$ & 100 \\
\hline 051111 & Garden and outdoor furniture & 10 & 100 \\
\hline 051211 & Carpets and floor coverings & 12 & 100 \\
\hline 053131 & Ovens, stoves and other heating equipment & 15 & 100 \\
\hline 053111 & Refrigerators and freezers & 13 & 100 \\
\hline 053121 & $\begin{array}{l}\text { Washing machines, tumble dryers, } \\
\text { dishwashers }\end{array}$ & 12 & 100 \\
\hline 053161 & Sewing and knitting machines & 20 & 100 \\
\hline 071111 & Cars (new) & 18 & 30 \\
\hline $\begin{array}{l}091111,091112- \\
091115\end{array}$ & Radios and other sound equipment & 10 & 10 \\
\hline 091121 & Televisions & 10 & 100 \\
\hline 054111 & Glasses and tableware & 15 & 100 \\
\hline 054121 & Cutlery and silverware & 15 & 100 \\
\hline 054131 & Cooking utensils (non-electric) & 15 & 100 \\
\hline 054132 & Other household articles (non-electric) & 15 & 100 \\
\hline 053211 & $\begin{array}{l}\text { Other electrical household equipment (e.g. } \\
\text { coffee makers, coffee grinders, kettles, } \\
\text { heaters, food processors, juicers) }\end{array}$ & $7-10$ & 100 \\
\hline 093211 & Fishing and hunting equipment with guns & 7 & 100 \\
\hline 093411 & Pets and pet supplies & 8 & 100 \\
\hline $\begin{array}{l}123221 \\
\& 123222\end{array}$ & $\begin{array}{l}\text { Other personal articles } \\
\text { (e.g. baby carriages, car seats, etc.) }\end{array}$ & 3 & 100 \\
\hline
\end{tabular}

* COICOP codes based on GUS [2009].

Source: own calculations based on [Błaszczak-Przybycińska, Marszałek 2015, p. 179].

Depreciation was estimated based on durable and semi-durable goods in households and the average period of exploitation for different groups of goods (Table 3). 


\section{Results of the valuation of household production in Poland}

The total output of household production in Poland in 2013 was 1,201.8 billion PLN. Gross value added in home production was 780.2 billion PLN, of which $15.3 \%$ was included in the national accounts (Table 4).

The results for 2013 correspond to the first Household Production Satellite Account for Poland in 2011 and 2013 [Błaszczak-Przybycińska, Marszałek 2015], when the home production registered in the GDP was estimated at 15\% [Marszałek 2015, pp. 162-163].

Table 4. Sequence of the Household Satellite Account for Poland in 2013 (in million PLN)

\begin{tabular}{|c|c|c|c|c|c|}
\hline \multirow{2}{*}{\multicolumn{3}{|c|}{ Specification }} & \multicolumn{3}{|c|}{$\begin{array}{l}\text { Monetary value of the components } \\
\text { of home production } \\
\text { (million PLN) }\end{array}$} \\
\hline & & & SNA & non-SNA & Total \\
\hline \multicolumn{3}{|c|}{ Value of the unpaid work (time $\mathrm{x}$ average wages) } & $\circ$ & 619,956 & 619,956 \\
\hline \multicolumn{3}{|c|}{ Housekeeping (SNA) } & 2,660 & $\circ$ & 2,660 \\
\hline \multicolumn{3}{|c|}{$\begin{array}{l}\text { Housing services produced by owner-occupiers, e.g. rents } \\
\text { (SNA) }\end{array}$} & 51,964 & $\circ$ & 51,964 \\
\hline \multicolumn{3}{|c|}{ Own-account construction of dwellings } & 40,163 & $\circ$ & 40,163 \\
\hline \multicolumn{3}{|c|}{$\begin{array}{l}\text { Growing foodstuffs, picking berries, mushrooms, etc., } \\
\text { hunting and fishing (SNA) }\end{array}$} & 6,773 & 3,454 & 10,227 \\
\hline \multicolumn{3}{|c|}{ Taxes on production } & 5,270 & 0,934 & 6,204 \\
\hline \multicolumn{3}{|c|}{ Subsidies on production } & $-13,455$ & $-21,574$ & $-35,029$ \\
\hline \multirow{5}{*}{$\begin{array}{l}\text { Current } \\
\text { Accounts }\end{array}$} & \multirow{2}{*}{$\begin{array}{l}\text { Generation of } \\
\text { income account }\end{array}$} & \begin{tabular}{|l|} 
Net value added \\
\end{tabular} & $\mathbf{9 3 , 3 7 5}$ & 602,770 & 696,145 \\
\hline & & $\begin{array}{l}\text { Consumption of } \\
\text { fixed capital } \\
\text { (depreciation) }\end{array}$ & 26,569 & 57,460 & 84,029 \\
\hline & \multirow{3}{*}{$\begin{array}{l}\text { Production } \\
\text { account }\end{array}$} & Gross value added & 119,944 & 660,230 & 780,174 \\
\hline & & $\begin{array}{l}\text { Intermediate } \\
\text { consumption }\end{array}$ & 256,708 & 164,869 & 421,577 \\
\hline & & $\begin{array}{l}\text { Output (household } \\
\text { production) }\end{array}$ & 376,652 & 825,099 & $1,201,751$ \\
\hline
\end{tabular}

Source: own calculations (revised and updated in accordance with the National Accounts data).

If household production is examined against the national accounts GDP, its share is $44.7 \%$ in 2013 (Figure 1). Household production included in GDP is counted at $8.1 \%$. In 2011 household production included in GDP was 807.3 billion PLN, of which $15 \%$ was included in the official statistics [Marszałek 2015, s. 163]. The difference between 2011 and 2013 is important and significantly large because of some crucial methodological reasons. Firstly, the valuation of unpaid work and household production in 2011 was based on the results of the Time use survey 2003/2004. In the first pioneer Household Production Satellite Account for Poland in 2011, the estimation of home production used some indicators to make 
adjustments, i.e. to make a recalculation of wages used to estimate the monetary value of the unpaid work. Secondly, household production included in the national accounts in 2013 covers more activities which are treated as productive unlike in previous years. In 2013 the Central Statistical Office of Poland implemented the newest methodological standards ESA2010 (European System of Accounts 2010) which provide the best practices and rules to calculate macroeconomic aggregates, i.e. global production, intermediate consumption, value added, capital formation, GDP etc. for all sectors in the economy.

Apart from the estimations of home production, the household satellite account is useful to measure and describe the proportion of household production to the official statistics and indicators, i.e. GDP.

\begin{tabular}{|c|c|c|}
\hline \multicolumn{2}{|c|}{ GDP in national accounts (in million PLN) } & \\
\hline \multicolumn{2}{|c|}{$1,477,161$} & \\
\hline GDP & Gross value added & Gross value added \\
\hline $\begin{array}{l}\text { (exclusive of household } \\
\text { production) }\end{array}$ & $\begin{array}{c}\text { Household production } \\
\text { (included in GDP) }\end{array}$ & $\begin{array}{c}\text { Household production } \\
\text { (not included in GDP) }\end{array}$ \\
\hline $1,357,217$ & 119,944 & 660,230 \\
\hline $91.9 \%$ & $8.1 \%$ & $44.7 \%$ \\
\hline \multicolumn{2}{|c|}{$100.0 \%$} & $+44.7 \%$ \\
\hline \multicolumn{3}{|c|}{ Extended GDP (in million PLN) } \\
\hline \multicolumn{3}{|c|}{$2,137,391$} \\
\hline $\begin{array}{c}\text { Market production } \\
\text { (without household sector) }\end{array}$ & \multicolumn{2}{|c|}{$\begin{array}{l}\text { Total household production } \\
\text { (SNA and non-SNA) }\end{array}$} \\
\hline $1,357,218$ & \multicolumn{2}{|c|}{780,174} \\
\hline $63.5 \%$ & \multicolumn{2}{|c|}{$36.5 \%$} \\
\hline
\end{tabular}

Fig. 1. Household production as a proportion of GDP in 2013

Source: own calculations.

If we work with the extended concept of an economy that includes household production, the results are rather different than the additional $44.7 \%$ when non-SNA home production is excluded from GDP. In the extended GDP indicator, household production accounts for $36.5 \%$ of the national economy in 2013. The results of household production and its impact on the economy (GDP) are comparable and the same proportions were obtained in 2013 and 2011 (Figure 1). Thus the analysis of market and non-market home production stay at the same level, hence confirming that non-market production made at home still has a huge role in the total productive activities carried out by household members. 


\section{Conclusions}

The Household Production Satellite Account is a concept of measuring and describing total home production carried out by household members for their own use. The value of home production is not only the products delivered to the market, but it is also the goods and services offered to other household members and to other households (family or neighbours). Overall, a stable and proper running household needs to realize a lot of a different physical, social, emotional and other needs of all the household's members. The gap which is observed in the national accounts could be filled by the supporting tool called HHSA. The household satellite account does not burden the public statistical system, it is rather an additional full sequence of accounts with comprehensive analyses of the real situation of households. HHSA does not interfere with the social statistics system, but it could fill the gap in that system.

Considering that the inclusion of non-market home production into the GDP has the same number of supporters and opponents, it is less complicated to analyse the productive role of households in the household satellite account than develop the extended GDP concept. In the near future economists and scientists should focus on highlighting home production, and it is supposed to be understandable and clearly explained in order to recognize the real socio-economic situation of households and to present the impact and transfers between generations and households to the general economy.

\section{Bibliography}

Becker G.S., 1990a, A theory of the allocation of time, The Economic Journal, No. 75, 299, pp. 493-517, www.unc.edu/ shanda/courses/plcy289/Becker_EJ Time.pdf (03.09.2018).

Becker G.S.,1990b, The allocation of time and goods over time, [in:] Becker G.S. (ed.), The Economic Approach to Human Behaviour, University of Chicago Press, Chicago, pp. 115-129.

Błaszczak-Przybycińska I., Marszałek M., 2015, Wycena wartości pracy własnej gospodarstw domowych na podstawie badania budżetu czasu, [in:] Budżet czasu ludności 2013. Cz. 1, GUS, Warszawa, pp. 131-183.

Błaszczak-Przybycińska I., 2005, Wycena pracy własnej gospodarstw domowych na podstawie badania budżetu czasu, [in:] Budżet czasu ludności 1 VI 2003-31 V 2004, GUS, Warszawa, pp. 76-98.

Błaszczak-Przybycińska I., 2007, Estimation of unpaid work in Polish households, Statistics in Transition, vol. 8, no. 3, pp. 547-561.

Błaszczak-Przybycińska, I., 2008, Produkcja gospodarstw domowych jako czynnik dochodotwórczy, (Household production as an income-generating factor), Oficyna Wydawnicza SGH, Warszawa.

Eurostat, 1999, Proposal for a Satellite Account Household Production, Eurostat Working Papers, 9, Luxembourg.

Eurostat, 2003, Household Production and Consumption. Proposal for a Methodology of Household Satellite Accounts. Theme 3 - Population and Social Conditions, Working Papers and Studies, Luxembourg. 
Fender V., 2012, Using an output approach to measuring household production, Office for National Statistics, Newport.

Fitzgerald J.M., Swenson M.S., Wicks J.H., 1996, Valuation of household production at market prices and estimation of production functions, Review of Income and Wealth, no. 2, pp. 165-180.

Goldschmidt-Clermont L., 1993, Monetary Valuation of Non-Market Productive Time. Methodological Considerations, Review of Income and Wealth, 199, no. 4, pp. 419-433.

Graham J., Green C.A., 1984, Estimating parameters of a household production function with joint products, Review of Economics and Statistics, no. 66, pp. 277-282.

Gronau R., Hamermesh D.S., 2008, The demand for variety: A household production perspective, The Review of Economics and Statistics, no. 3, pp. 562-572.

Gronau R., 1980, Home production - a forgotten industry, Review of Economics and Statistics, no. 62, pp. 408-416.

GUS, 2009, Klasyfikacja spożycia indywidualnego wedhug celu do badania budżetów gospodarstw domowych (COICOP/HBS). Zeszyt 2. Instrukcji organizacyjno-metodologicznej do badania budzetów gospodarstw domowych na lata 2009-2012, ZWS, Warszawa.

GUS, 2014, Struktura wynagrodzeń wedlug zawodów w październiku 2012 r., (Survey of Wages According to Professions 2012), ZWS, Warszawa.

Hamunen E., Varjonen J., Soinne K., 2012, Satellite accounts on household production: Eurostat methodology and experiencies to apply it, http://www.iariw.org.

Hawrylyshyn O., 1976, The value of household services: A survey of empirical estimates. The Review of Income and Wealth, no. 22, pp. 101-131.

Holloway S., Short S., Tamplin S., 2002, Household Satellite Account (experimental) Methodology, http://www.ons.gov.uk/ons/search/index.html?newquery=Household+satellite+account\&newoffs et $=100 \&$ pageSize $=100 \&$ sortBy $=$ pubdate \&sortDirection=DESCENDING\&applyFilters=true (03.09.2018).

Ironmonger D., 1996, Time use and satellite accounts for modelling the household economy, Paper presented in the IARIW 24th General Conference, Norway.

Ironmonger D., 1997, National Accounts of Household Productive Activities, Paper presented in Time-Use Non-Market Work, and Family Well-being, A conference co-sponsored by the Bureau of Labour Statistics and the MacArthur Network on the Family and the Economy, BLS, Washington DC.

Kuwahara S., 2010, A note on monetary valuation of unpaid work in Japan, Working Party of National Accounts, 9, http://www.oecd.org/std/na/46640700.ppt (03.09.2018).

Marszałek M., 2015, Rachunek produkcji domowej w Polsce $w$ koncepcji systemu statystyki spotecznej (Household Production Account in Poland in the concept of the social statistics system), Oficyna Wydawnicza SGH, Warszawa.

OECD, 2010, Incorporating estimates of household production of non-market services into international comparisons of material well-being, Working paper, no. 42, http://www.oecd.org/ officialdocuments/publicdisplaydocumentpdf/?cote $=$ std/doc $\% 282011 \% 297 \&$ doclanguage $=$ en (03.09.2018).

Poissonnier A., Roy D., 2013, Household Satellite Account for France in 2010. Methodological issues on the assessment of domestic production, Institut National de la Statistique et des Études Économiques, France.

Rapoport B., Sofer C., Solaz A., 2011, Household production in a collective model: Some new results, Journal of Population Economics, vol. 24, issue 1, pp. 23-45.

Reid M., 1934, Economics of Household Production, Wiley, New York.

Ruger Y., Varjonen J., 2008, Value of household production in Finland and Germany: analysis and recalculation of the Household Satellite Account System in both countries, National Consumer Research Centre, Helsinki. 
Schäfer D., 2004, Unbezahlte Arbeit und Bruttoinlandsproduct 1992 und 2001. Neuberechnung des Haushalts-Satellitensystems, Statistiches Bundesamt, Wiesbaden.

Stiglitz J., Sen A., Fitoussi J.P., 2009, Report by the Commission in the measurement of economic performance and social progress, http://www.stiglitz-sen-fitoussi.fr/documents/rapport anglais.pdf (03.09.2018).

Szép K., 2003, Összefoglalás helyett - A Nemzeti Számlákban nem Kimutatott Háztartási Termelés Termelési Számlája és a Jövöbeli Feladatok, [in:] A Háztartási Termelés Ertéke a Mai Magyarországon (Household Satellite Accounts, Statistical Sampling and Methodology Section), Hungarian Central Statistical Office, Budapest.

Varjonen, J., Aalto, K., 2006, Household Production and Consumption in Finland 2001. Household Satellite Account, Statistics Finland, and National Consumer Research Centre, Helsinki.

Varjonen J., Aalto K., 2010, Kotitalouksien palkaton tuotanto ja ostopalvelujen käyttö, (Households' unpaid production and use of market services), National Consumer Research Centre, Helsinki, http://www. kuluttajatutkimuskeskus.fi/files/5455/2010_02_julkaisu_kotsa.pdf (03.09.2018).

Varjonen J., Hamunen E., 1999, Proposal for a Satellite Account of Household Production. Agenda Item 1, Statistics Finland, OECD Meeting of National Accounts Experts, Paris.

Varjonen J., Niemi I., Hamunen E., Sandström T., Pääkkönen H., 1999, Proposal for a Satellite Account of Household Production, Eurostat Working Papers, 9.

\section{RACHUNEK SATELITARNY PRODUKCJI DOMOWEJ. UWAGI METODOLOGICZNE I WYNIKI DLA POLSKI}

Streszczenie: Jednym $\mathrm{z}$ większych agregatów, niemających odzwierciedlenia w aktualnym systemie europejskich rachunków narodowych, jest produkcja gospodarstw domowych. Rynkowa wartość tej produkcji stanowi niespełna 10-15\% łącznej produkcji domowej. Do wyceny produkcji domowej najczęściej wykorzystywana jest metoda nakładu. Podstawowym nakładem jest tutaj nieodpłatna praca domowa. Proponowane były różne metody i techniki wyceny tej pracy, ale wielu ekonomistów preferuje metodę stawek rynkowych. Pierwszy pełen rachunek produkcji domowej dla Polski opracowano dla 2011 roku. Ustalono, że wartość pracy domowej stanowi ok. 80\% łącznej wartości produkcji domowej, zaś całkowita wartość produkcji domowej w relacji do PKB wyniosła ok. 52,8\%. Opracowanie satelitarnego do rachunków narodowych rachunku produkcji domowej pozwoli na rozpoznanie i lepsze zrozumienie transferów i interakcji zachodzących między rynkiem i gospodarstwami domowymi. Wartość i rozmiar wytworzonych przez gospodarstwa domowe dóbr i usług mogą być porównywane $\mathrm{z}$ analogicznymi produktami wytworzonymi na rynku przez przedsiębiorstwa.

Słowa kluczowe: produkcja domowa, praca domowa, rachunki satelitarne, PKB. 